\title{
(Q)
}

\section{Ruins of Resilience: Imaginaries and Materiality Imagineered and Embedded in Civil Defence Architecture}

\author{
Rosanna Farbøl
}

In April 1951, Director General of the Danish Civil Defence Directorate (DCDD) Arthur Dahl went on a study trip to the UK. During the course of his stay, he visited the British Civil Defence technical school at Eastwood Park, near Bristol, where he was particularly thrilled by a unique feature: a village that looked like it had been destroyed by atomic bombs. There were bombed-out houses, streets blocked by debris, a crashed airplane and an overturned truck. In these authentic surroundings, civil defenders were trained in basic rescue, firefighting, debris clearance, handling of gases and first aid. ${ }^{1}$ The debris and rubble of this ruined village gave 'mass and solidity' (Jasanoff 2015b: 322) to the imaginary and dystopian war civil defence prepared for. Upon his return to Denmark, Dahl declared that a similar facility, a town of and in ruins, was 'absolutely necessary' in Denmark, at least in the capital, Copenhagen, to

R. Farbøl (凶)

Department of History, University of Southern Denmark, Odense, Denmark e-mail: rosfa@sdu.dk

(C) The Author(s) 2022

M. Cronqvist et al. (eds.), Cold War Civil Defence in Western Europe, https://doi.org/10.1007/978-3-030-84281-9_7 
improve the education of civil defence instructors. ${ }^{2}$ Realistic ruins were needed to make the instructors capable of performing their vital skills under the direst circumstances, a nuclear war. In this Cold War vision, ruins were key to resilience and national survival.

From the outset of the Cold War, it was generally recognised that in the next war civilians and not just military installations would be targets of atomic bombs. Cities were considered particularly vulnerable. In consequence, the Danish welfare state sought to protect its citizens through a system of civil defence and emergency planning - in return, of course, for the loyal collaboration of the citizens and on the assumption that the citizens themselves contributed to basic civil defence (Bjørnsson et al. 2020). Undoubtedly, the nuclear condition placed this social contract under stress; particularly with the advent of the $\mathrm{H}$ bomb, the state was, in fact, unable to offer total protection from total nuclear war. Still, the ruins could demonstrate to civil defenders and ordinary citizens alike how plans for protecting the population in the imagined aftermath of a war were real: they were based on the material realities of built structures of everyday environments.

Drawing on ruinology literature ${ }^{3}$ and on scholarship associated with New Materialism, this chapter focuses on the ruin as both physical form and representation in the analysis of the Danish civil defence's preparation, performance and imagination of a Third World War. The chapter contends that the ruin 'imagineered' (Monteyne 2011) a stage for enacting and performing a future war, whereby the merely imagined was given a concrete, tangible expression. The ruin town added materiality, spatiality, realism and presence to what was largely speculative, discursive and imaginary.

This chapter sketches the transnational extension of the British model ruin to Denmark and examines how the ruin town travelled to a new national context and was appropriated to local needs (and restraints). In Denmark, the ruin town embedded a sociotechnical imaginary that emphasised resilience, survival and regeneration, where welfare triumphed over warfare. Then, disrupting the ostensible linearity in the 'life cycles' of sociotechnical imaginaries (see the Introduction to this book), the chapter demonstrates that the ruin town was re-extended all over the country through a standardisation of ruins that fostered homogeneity and uniformity to become part of the common Danish civil defence landscape, while simultaneously serving to re-embed the imaginary in local contexts. The 
chapter, finally, discusses whether these ruin towns contributed to an affirmation of social norms and values, arguing that they, in fact, caused a 'taming' (Clark 1999) of the nuclear catastrophe, as well as reflecting and reinforcing a specific political and historically situated understanding of social order and the 'good society'.

\section{Ruins and CATASTrophe IMAgineERED}

The ruin is an ambiguous structure that can signal both the loss and the endurance of the past. As physical structure and representational form, the ruin complicates intellectual dialectics between absence and presence, fragment and whole, universal and specific, utopia and dystopia. Gazing at ruins, we not only see the actual structure but also draw on a transhistorical iconography of decay and catastrophe, a 'vast visual archive of ruination' (Hell and Schörle 2010: 1). Though ruins are usually seen as tokens of darkness, death and degeneration, they are also associated with romanticism, gothic tales and the sublime, and taken as heralds of hope, new beginnings and the ability of humans to shape the future (Edensor 2005; Eshel 2010). The Cold War ruin town must be understood as embodying both: it represents abyss and redemption, obliteration and resilience. It offered a spectacular stage for the 'performative dimensions of society's self-reproduction' (Jasanoff 2015a: 5), a stage for enacting, or, we might say, pre-enacting (Sylvest 2021), the ability of society to overcome the war and extend existing ways of life into a postwar future.

In 1984, Derrida famously stated that nuclear war was 'fabulously textual' (Derrida 1984: 23): it depended on structures of information and communication because a nuclear war had not taken place. It was, and still is, a non-event (the atomic bombs over Japan in August 1945 ended a conventional war, but they did not spark a nuclear one). The ruin town, however, gave the fiction of war a materiality, a presence beyond discourse. Architectural historian David Monteyne has coined the phrase 'imagineering' to describe the merging of concrete, tangible engineering and architecture with fantasy and imagination (Monteyne 2004, 2011). The ruin town is an often overlooked yet striking example of the apocalyptic city imagineered. It represented the ordinary, everyday townscape rendered into a violent, catastrophic urban battlefield. These civil defence environments made it possible to rehearse and enact the imaginary war in realistic, palpable settings and provided immediate physical as well as sensual access to experiences that seemed to defy representation. 
The construction of ruins was a way of mitigating disaster. The ruin town signalled a belief that material structures, the built environment and technical skills could offer protection (Deville et al. 2014), while it also in itself constituted a materialisation of the conception of risk. It is important to keep in mind that it is not just the material structure as such that matters but the co-production (Jasanoff 2015a, b) of the ruin and the ideas, fears and ambitions that turn imaginaries into practice and comes to constitute a social reality. The townscapes were, on the one hand, a result of the imagination of civil defence officials and technicians: they literally set in stone the official civil defence sociotechnical imaginary of what a future war would look like and how it could be prepared for based on the capabilities of the organisation. On the other hand, it in turn came to define and structure the imagination, fostering a certain inertia and immutability.

In highlighting the material powers of the ruin towns, I am inspired by approaches of New Materialism that attempt to overcome 'the enduring separation between thing and meaning, concrete and abstract, physical and mental' (Ireland and Lydon 2016: 2) by shifting analytical focus from what things mean to what they $d o$. These insights are useful to substantiate and operationalise Jasanoff's notion of materiality, which often appears simply to mean technology (Jasanoff 2015a: 8, 20, 22; 2015b: 324). The concept of 'the material' in this chapter refers in an intentionally ambiguous manner to both the material substances (the built structures and infrastructures of the ruin town) and 'the palpable power effects flowing from the strategic arrangement of material objects' (Frohman 2011). Like shelters or scale models, ruin towns not only reflected risk but also produced, performed and transformed risk and preparedness by materialising statements of the plausibility of war and concretising the idea of state-led preparedness and protection (Deville et al. 2014; Puff 2010). The buildings not only framed but also structured the anticipated event. Ironically (but following the logic of co-production), in the attempt to provide technological solutions for an attack feared likely or even inevitable, the architects of the ruin town contributed (psychologically) to the very construction of the probability or inevitability of this event.

The architect Eyal Weizman suggests that 'the ruin has an 'architecture' in which controversial events and political processes are reflected and from which they might be reconstructed and analysed' (Weizman 2011: 111). While Weizman is concerned with the authentic ruins of Gaza, his 
approach of 'forensic architecture' (Weizman 2012) can be employed in the study of the artificial ruin town because it is not just an illustration of (anticipated) violence but a source of knowledge about historical tensions, social norms, expectations and fears. As an embedding of a sociotechnical imaginary, it is not innocent but must be understood in a specific historical, social and political context that simultaneously shaped and was shaped by rationalities, behaviours and imaginations of future (and past) $\operatorname{war}(\mathrm{s})$.

I have combined these theoretical approaches with original field investigations in a selection of ruin towns still in existence (and use) in Denmark. I have analysed and compared the ruins, interiors and exteriors, as well as the spaces between the ruins, the infrastructures and general townscapes. I have consulted the Danish National Archives, local archives and municipal building construction archives to track down blueprints, situation plans, and technical and statistical calculations, as well as correspondence between the DCDD, local civil defence, contractors, architects and engineers. Finally, I have employed a wide array of national and regional newspapers in order to examine the impact of the ruins on national and local communities and identities.

\section{Getting TO DENMARK}

A couple of months after Arthur Dahl had returned home from his visit to the UK, he sent the DCDD's preferred architect F. Grut and Brigadier Chief O. P. Petersen to inspect the technical school at Eastwood Park with the aim of establishing a similar structure in Denmark. They were received by architect Lewis E. Trevers, Home Office Consultant for technical schools. Trevers suggested that a Danish training ground be initially constructed as a set of few buildings with multiple purposes instead of multiple, single-purpose buildings like Eastwood Park. This would reduce the estimated costs to around DKK 300,000-400,000. According to Trevers, the total construction costs of Eastwood Park had been approximately DKK 1,200,000. ${ }^{4}$ A gradual expansion could then take place every year with financial allocations on the national budget.

Both Grut and Petersen made reports following their visit, which make it possible to trace their journey and impressions. Clearly amazed by the facility, Petersen described how training was conducted in the village and specified which civil defence functions (including rescue, work in confined spaces, reinforcing buildings) each of the buildings served. ${ }^{5}$ Grut's report 
was more technical in nature. Focused on the professional construction of realistic ruins, he detailed how the more or less undamaged part of a building was constructed in an ordinary fashion. Then, debris was added based on a combination of empirical knowledge and technical calculations. Grut made an apt observation when he remarked that ' $t \mathrm{t}$ ] he planning of the construction as a whole, moreover, demands a not inconsiderable display of imagination in order to obtain as realistic an effect as possible'. ${ }^{6}$ Back in Denmark, architect Grut set to work designing a training ground based on his notes, photographs and sketches. However, a lack of funding meant that Dahl and Grut's ambitious plans for a ruin town near Copenhagen were shelved. The idea, nevertheless, was realised elsewhere, where there were fewer bureaucratic restraints on the display of creativity.

At the civil defence barracks in Tinglev, a village in the countryside of Southern Jutland (about as far from Copenhagen as possible), section leader K. M. Nielsen set about acquiring a bombed-out village-or ruin town as it became quickly known-for the training of his detachment of the South Jutland mobile column. ${ }^{7}$ With assistance from platoon leader (and architect by training) L. Weisdorf, a blueprint was drawn up (Fig. 7.1).

The ruins were built between 1952 and 1955 by conscript personnel in their spare time using only free materials from houses designated for demolition in the vicinity. ${ }^{8}$ Initially, the ruin town contained four blocks of houses consisting of six one- to two-storey houses, including a shop and a church-like tower, as well as some wooden sheds. The houses were located around a main street (Storegade), a parallel street called Fire Avenue (Brandallé) and two smaller streets across. As a whole, it represented a fragment of an urban environment. More buildings were soon built, including a three-storey factory, and a short stretch of railway tracks was added as well. As it turned out, the approach was not unlike the one Trevers had originally suggested. The streets were blocked by rubble and debris, as well as crashed cars, buses and trams. ${ }^{9}$ Telephone poles, sewers, electricity and gas were installed, so personnel would also have to take this utility infrastructure (or, rather, broken infrastructure) into account during the exercises. The recruits would face burning houses, smoke or gas-filled basements, and there would be live casualties to be rescued from the buildings. A loudspeaker installation was used to make sound effects, such as of air raids. ${ }^{10}$ The exercises often took place after sunset, and the scene was set for an inferno: a town ravaged by firestorms and reduced to 


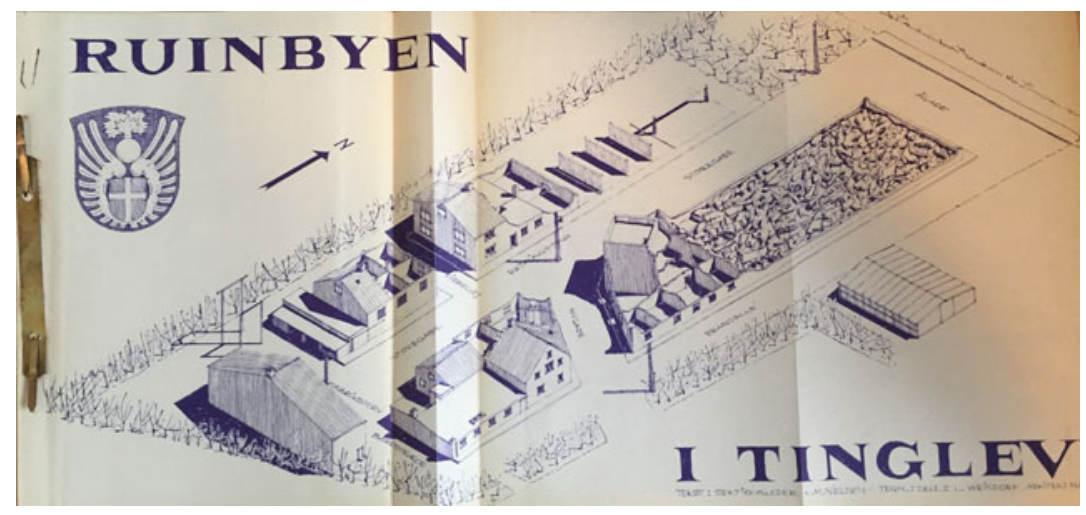

\section{Fig. 7.1 Plan of Tinglev}

(Original plan of Tinglev as envisioned by K. M. Nielsen and L. Weisdorf. The factory looks out over Main Street (Storegade), which is outlined by houses in various stages of ruination. To the North-East is an area of concrete debris that were used for practising how to run with stretchers and victims across impassable terrain. Printed with permission from S. Weisdorf)

ruins, the screams of victims filling the night. Training in the ruin town was a corporeal and sensory experience as well as a practical one.

According to Arthur Dahl's successor as director of the DCDD, Erik Schultz, Tinglev ruin town was not perfect from an educational perspective because it was constructed on an ad hoc basis instead of according to Grut's original master plan. Still, it was functional and, significantly, cheap. Schultz estimated the costs at a few thousand DKK, though he stressed that, in effect, it was worth far more. ${ }^{11}$ The cost efficiency was also noted smugly in a newspaper article in Horsens Social-Demokrat, which compared Tinglev to the British prototype. Exaggerating a good deal, the paper asserted that they were 'similar in size and construction'. 12 Tinglev ruin town quickly became a national source of pride. An article in the national newspaper Jyllands-Posten described it as 'an outdoor school room, where it is possible to create all the situations that will arise if the destruction of a war hits the civilian population in an urban area', 13 revealing an expectation that due to the ruin town, the future had become knowable and possible to prepare for: this was what war would look like in Denmark.

Danish newspapers celebrated Tinglev as unique (on the European continent) and revelled in the fact that visitors came from all over the 
country and abroad on civil defence study trips. The guests were most often from Scandinavia, but also from the other Nordic countries, as well as Germany and the UK. More exotic visitors included Saudi and Thai delegations. ${ }^{14}$ The ruin town quickly grew to be the largest training ground in Northern Europe-and, at the time of writing, it still is - and the narrative changed from Tinglev being modelled on Eastwood Park to Tinglev being a template for others.

The success of the ruin town must account for the fact that Tinglev was chosen to become the (only Danish) Civil Defence Technical School in 1956. Instead of being a training ground for the local mobile section, Tinglev was now a national school where conscripts and volunteers from all over Denmark came for technical education and practical training. That meant considerable development and extension of the main building as well as the ruin town. Though initially sidelined, the DCDD now took charge. Architect Grut was called upon to do the work, and it appears likely that some of his original drawings may have been put to use. ${ }^{15}$

\section{Building the Perfect Ruins}

During the 1960s, ruin towns mushroomed all over the country. A revision of the Danish Civil Defence Act in 1962 introduced conscript personnel to local civil defence in provincial towns, something local authorities had long called for due to problems attracting sufficient numbers of volunteers. With the sudden influx of large numbers of conscripts, a need arose for better educational facilities locally. In 1962, the DCDD decided to spend initially DKK 1.9 million on building ruin towns. Six larger provincial towns were selected as the first to receive funding for ruin building: Aalborg, Randers, Holstebro, Esbjerg, Århus and Odense. ${ }^{16}$ Just a decade later, there were 26 ruin towns spread across the seven Danish civil defence regions. ${ }^{17}$ It is not without irony that at the same time as geopolitical détente thawed the Cold War climate internationally, the imaginary war materialised in earnest as an urban reality in Denmark. ${ }^{18}$

Local authorities perceived ruin towns as vital to civil defence training and were eager to start building their own. The four towns of Kolding, Vejle, Fredericia and Middelfart decided as early as 1961/62 to join forces to build a common ruin town despite receiving no financial assistance from the DCDD (CF-samvirket Gudsø 1987). The importance and value of ruin towns seem to have been shared more generally by the local 
communities. When a town started building their own ruins, local newspapers celebrated the event. It was clearly a matter of great prestige and identity, as if the risk of becoming a target of the enemy's assault marked the town as particularly important. On 22 May 1966, the local paper Vendsyssel Tidende proudly reported that the ruin town that was being built in Hvims, Northern Jutland, 'can already demonstrate significant achievements even though it is only half-finished', and that local civil defence had 'already benefited greatly' from it. ${ }^{19}$

The ruin towns were all centred on the so-called standard ruin (Fig. 7.2). It was the perfect ruin. First, it was realistic in two ways: it

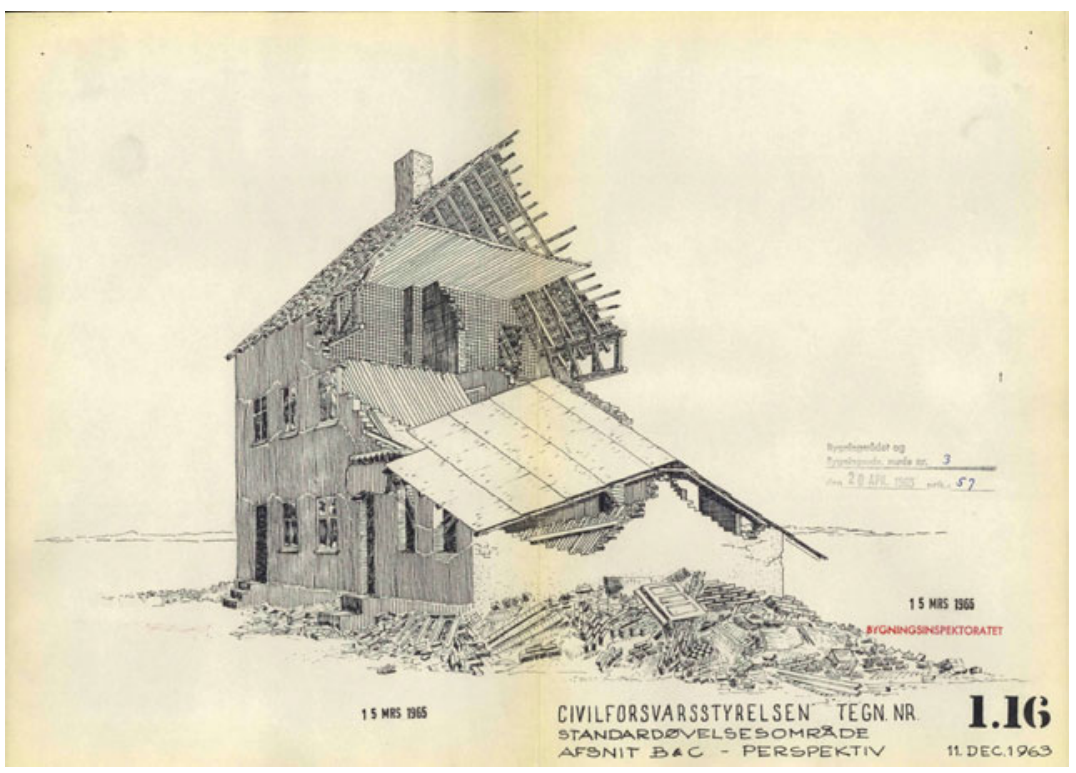

Fig. 7.2 DCDD blueprint of standard ruin, 1.16 Structures B and C, perspective

(Structure B imitated a relatively unharmed building with an intact ground floor, partly damaged first floor and attic. C was a heavily damaged building, where it was just possible to discern the structure of walls at ground floor; the above floors were completely damaged. In addition, there was an undamaged basement. In order to protect the interior from bad weather, a flat roof construction covered the building. The pile of rubble in front of the houses was the "remains" of a completely ruined building A. Source Aalborg Kommune Byggesagsarkiv C183161965 ) 
looked like a real ruin, and it resembled common Danish townhouses. Second, it was safe: the training would not become too realistic as a result of actual collapse. Third, it was created with the essential civil defence tasks in mind. The standard ruin consisted of five buildings, named A-E, which represented the remains of five originally neighbouring houses in various stages of ruination. ${ }^{20}$ (Figs. 7.3 and 7.4).

The buildings embodied different types of collapse as described in the Basic rescue textbook (Civilforsvarsstyrelsen 1965), fitting them for use in civil defence exercises for different types of rescue operations. The textbook did not differentiate between damage caused by conventional or nuclear bombs (Civilforsvarsstyrelsen 1965: 58). The rationale was that the main difference between the two concerned the extent of the damage and only to some degree the character of rescue tasks. The latter mainly referred to the location of potential victims, as they would not primarily be located in basements but on all storeys, because modern weapons technology (rockets and short warning times) meant that people would have little time to seek shelter (Civilforsvarsstyrelsen 1965: 58). The corresponding textbook about firefighting likewise operated with few distinctions between a conventional and a nuclear attack and drew heavily on the experiences of the Second World War (particularly the fire storms in German cities). The book noted that the nuclear attacks on Japan caused similar fire phenomena, and therefore, conflagrations would likely occur no matter what kinds of weapons were used in a future war (Civilforsvarsstyrelsen 1971: 71).

The standard ruin was built according to a fixed set of architectural blueprints developed by the DCDD. This made it possible to re-create the ruins almost identically everywhere, and the ruins became in a sense trans-spatial. In order to receive financial assistance for the construction of a ruin town, local civil defence had to use the official blueprints for the standard ruin. This ensured a standardisation of ruin building and a uniformity and homogeneity of ruins across Denmark. To make a proper ruin town, however, the standard ruin would be supplemented with other ruined buildings.

The Danish ruin towns were emulating 'X-town' ( $X$-købing), a fictive but generic and conventional market town that regularly suffered attack in civil defence war games, films and planning material. Built structures typical of Danish provincial towns and common street names made the townscapes familiar and recognisable, yet not specific enough to be identifiable as one particular town. The exercises in the ruin towns were meant 


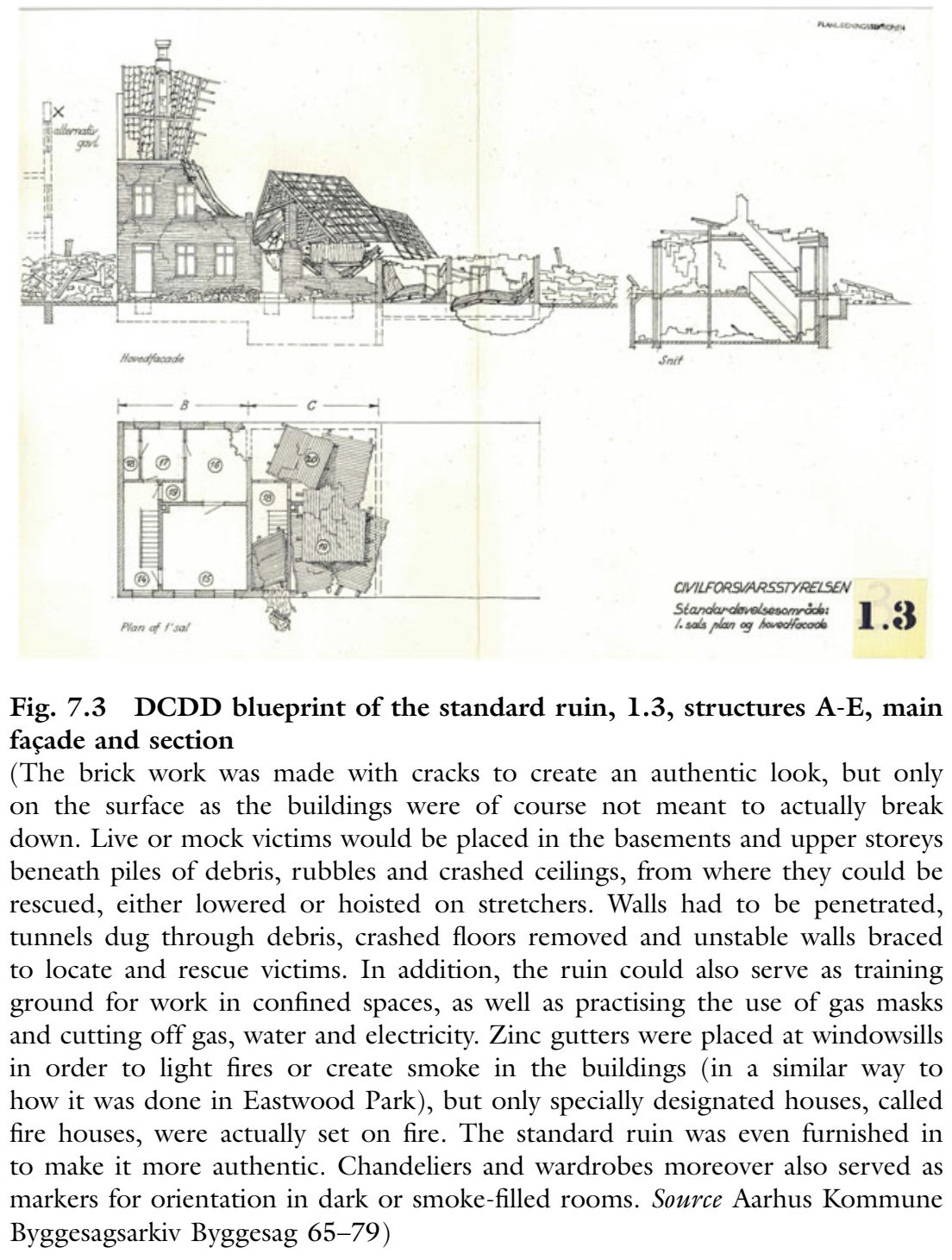




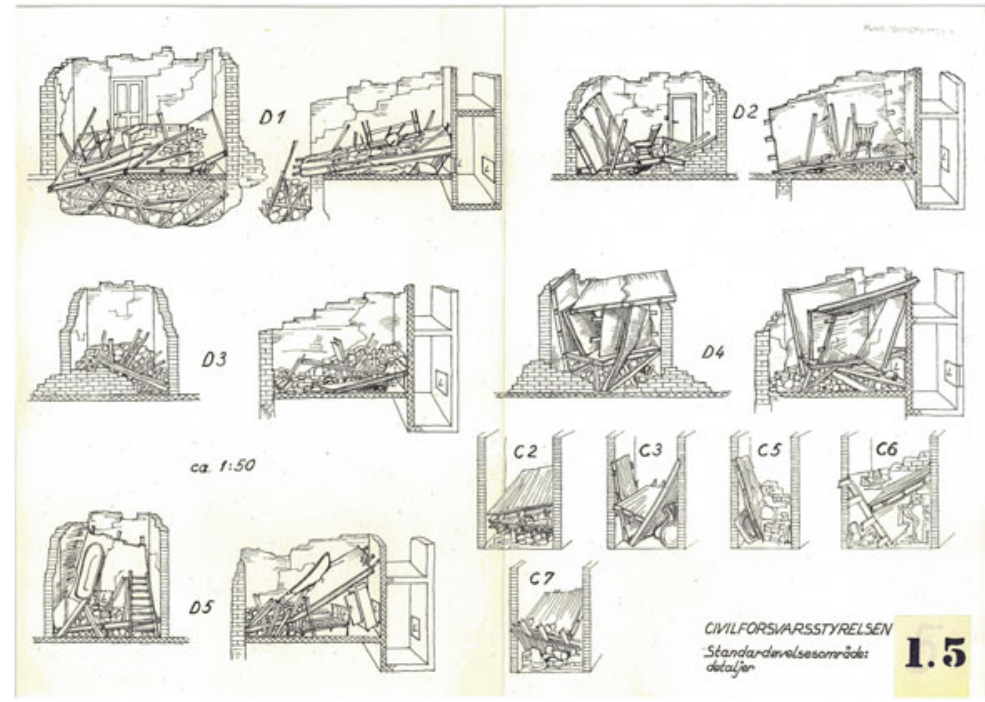

Fig. 7.4 DCDD blueprint of the standard ruin details from structures C and $\mathrm{D}$

(Details from structures C and D. Detail drawings meticulously noted where and how debris, crashed ceilings and floors as well as furniture should be placed in order to ensure safety as well as facilitating different training tasks. Source Aarhus Kommune Byggesagsarkiv Byggesag 65-79)

to hit close to home for all civil defenders and encourage a sense of responsibility: this could be their hometown... in ruins. Leader of Hvims ruin town, J. C. Kristensen, told a local newspaper in 1966 that the ruin town had given his men a better understanding of the necessity of the training and made them more enthusiastic. ${ }^{21}$ It confirmed the value of their work, reinforced the credibility of civil defence and strengthened the personnel's collective identity as humanitarians. In this way, the ruin towns contributed to processes of embedding the civil defence sociotechnical imaginary in local communities.

The scale and extent of ruin towns varied across the country, which may reflect different local attitudes towards civil defence, as well as different financial situations. Some ruin towns were small and modest. In Odense on the island of Funen, the standard ruin remained solitary until supplemented during the 1970s by two other buildings. ${ }^{22}$ Other ruin towns quickly outgrew their humble origins. At Kirstinesminde, just 
north of Aarhus in Eastern Jutland, several streets and a dozen groups of buildings, including two fire houses and two fire ruins, were constructed. In 1976, a so-called 'corner building' was planned and built. ${ }^{23}$ It was based on blueprints from similar buildings in Esbjerg and Aalborg, which testifies to a translocal circulation of ideas and materialities.

The corner building was a modern type of multistorey housing block built in aerated concrete. In the 1970s, this kind of built structure had begun to replace the traditional Danish brick house as the preferred building type, and it collapsed in entirely different ways, hence creating a need for updated ruins. Though this development occasioned the inclusion of a new building design, the scenarios and the training changed little.

\section{Performing and Taming Nuclear Catastrophe}

According to the instigator of Tinglev, K. M. Nielsen, the ruin town was 'a training ground where the personnel could receive education in basic rescue in as realistic conditions as possible so that no task in actual conditions would appear unfamiliar to them'. ${ }^{24}$ The quote reveals a utopian belief that all scenarios could be predicted, planned, prepared for and performed. War, whether nuclear or conventional, could be pre-enactednot re-enacted, as it had not yet occurred-and rehearsed in authentic environments.

The ruin town was not meant to simulate ground zero, zone $\mathrm{A}$, of a bombed town, but rather zones $\mathrm{B}$ and $\mathrm{C}$ further out. Not a metropolis, nor a village, the ruin town represented an intersection between the doom of the urban ground zeros and rural safety. The building structures had suffered heavy damage, but they were not completely obliterated. There were casualties but also many survivors to be rescued. In short: catastrophic but not apocalyptic.

The tasks that were practised in the ruin towns were mainly basic rescue and first aid, firefighting and debris clearance: tasks that would be difficult - if not impossible - to carry out if an area had been contaminated by radioactivity. ${ }^{25}$ In 1966, Tinglev started to offer tactical courses on protection against weapons of mass destruction (in Denmark called ABC weapons: atomic, biological and chemical), and in the 1970s, simulated nuclear bombs were exploded as part of the course. ${ }^{26}$ Yet practical civil defence exercises in the ruin towns seem to have been mainly based on scenarios of conventional attacks. ${ }^{27}$ Horrifying as these may have been, 
the lack of explicitly nuclear conditions is remarkable, not least given the increasing public attention to the dangers of radioactivity, particularly after the US H-bomb tests on the Bikini Atoll in 1954.

During the 1980s, there was a renewed focus on nuclear and chemical weapons in both Danish public debate and the civil defence organisation. A special Atomic Chemical Officer course was established in 1983, and the practical courses at Tinglev included instruction in how to wear protective clothing, use dosimeters and other measuring equipment, and how to cleanse after exposure to radioactivity. ${ }^{28}$ The exercises also include scenarios of radioactive contamination. ${ }^{29}$ However, the main focus continued to be firefighting and rescue, and the textbooks from the 1960s were still in use. The pragmatic reasoning within the organisation was that close to an urban ground zero in a thermonuclear attack, there would be nothing they could do, and thus no point in training for it. Furthermore, such an attack would leave few survivors and thus, paradoxically, less work for the civil defence (mass burials of the dead were not a civil defence task). In contrast, the conventional scenarios would demand a huge effort on the part of the civil defenders.

Following this line of reasoning, the original core activities of putting out fires and rescuing people from buildings and shelters would be similar after either a nuclear or a conventional attack, even if the circumstances were not. ${ }^{30}$ Training for nuclear war simply added the extra dimension of being attentive to levels of radiation and getting out when these levels constituted a lethal danger to personnel, a challenge each individual civil defender was thought capable of dealing with. Whether a pragmatic and rational approach or a form of nuclear 'psychic numbing' (Lifton 1982), the attitude attuned the perception of personnel to the threat and how to live with it. Nuclear war was effectively normalised as just another war scenario that could be prepared for in the same way as non-nuclear war, and civil defence work was rationalised as functional, useful and important no matter the circumstances (see also Hogg this volume). By defining and explicating the threat, the materiality of the ruins rendered alternative scenarios invisible or insignificant, and the effect was the construction of a consensus about danger, preparedness and resilience.

The ruin town can be seen as a stage for 'performative occasions' (Jasanoff 2015a:11): training and exercises were carefully planned and orchestrated actions resulting - ideally - in familiarisation with the danger, as expressed by Nielsen. After the Cold War, international historical research often used theatre metaphors to describe civil defence (Davies 
2007). This comparison was not unfamiliar to the historical actors themselves, however. Architect Grut remarked in his report following the study trip to Eastwood Park that the ruin town 'to some degree resembles a stage setting that must be constructed with a thorough sense of realism'. ${ }^{31}$ By pre-enacting the future war in highly detailed and often publicised spectacles of theatrically rehearsed destruction in the ruin towns, the personnel were trained bodily, emotionally and mentally to instil in them experiences and habits that could be mobilised in times of crisis. Enacting the routines in the ruin town again and again can be interpreted as transforming or 'taming' (Clark 1999) an unknown, incomprehensible and incalculable catastrophe, nuclear war, into a familiar and manageable urban calamity, collapsed buildings and fires.

The ruin town offered a possibility of confronting the unknown and unfathomable catastrophe, naming it, articulating it and thus disarming it. Though scary and disturbing, the ruin towns were manageable places of destruction. They were not spaces of despair or hopelessness. Rather, they promised victory, hope and a new beginning in the postwar future. Training and exercises among the ruins demonstrated that knowledge, experience, strength and willpower (and the right technical equipment) were all that was needed to sort out chaos and re-establish the prewar social order. Far from being a radical utopian desire for a tabula rasa and an urban renewal following a nuclear apocalypse (Monteyne 2011), the ruin town can be seen as the (willed) triumph of everyday life in the provincial town, and the desire to extend existing norms and ways of life into the postwar situation.

The technoscientific imagineering of disaster potentially had social effects beyond civil defence circles. The ruin towns were used as the setting for civil defence propaganda films for a broader audience, and they featured frequently in local and national newspapers. Through these mediations, the ruin town subjected the war to public admiration (rather than scrutiny). ${ }^{32}$ Without fail, the newspapers stressed the realism and authenticity of ruin towns and took pride in how these environments were (allegedly) capable of imitating the abysmal reality of nuclear war. ${ }^{33}$ The notion that local civil defence forces always managed to combat the danger and rescue the (fictive) inhabitants was celebrated, for instance by the local paper Vestkysten, which in 1962 ran the headline: 'The efficiency of Esbjerg Civil Defence proven by realistic exercise in Tinglev'. ${ }^{34}$ Even when a civil defence exercises actually demonstrated weaknesses or 
flaws, the papers often managed to turn the narrative around to something positive. In 1975, the national paper Jyllands-Posten reported on an exercise conducted by the national Civil Defence Corps. The paper stressed that despite severe budget cuts for years, civil defence was still capable of carrying out their tasks. There had been challenges for the exercise, however, the paper lamented, specifically the conscripts' lack of enthusiasm, which was caused by their disapproval of the war scenario. The conservative paper gave a thinly veiled critique of the indolence of the youth and their lack of understanding the seriousness of the Communist threat, which caused them to rebel. Still, the paper reassured the readers; in the end, the exercise was successful due to the untiring efforts of the officers. ${ }^{35}$ The population could rest assured that rescue was indeed possible, even likely-if, of course, they acted rationally and behaved according to the instructions of the authorities.

The ruin town was 'politics in matter' (Weizman 2007); it staged public rituals and technoscientific practices, repetitive performances of statehood and democratic participation that formed an act of governance. The average Danish main street was cast as the target of the enemy's assault, but through rehearsing and pre-enacting, the state demonstrated, embodied and manifested its promise to take care of its citizens and re-establish social order. That particular social order was the modernistic, functional welfare state. Welfare and civil defence ideologies were alike in promoting the ideal of the rational, well-prepared citizen of modern society (in this case, the educated civil defence personnel) who contributed to the common good and survival of society by fighting and controlling the threat posed by global and total war. Performing the work in the ruin towns depended on everyone fulfilling their specific and vital task in solidarity with and for the benefit of the larger whole, which reflected a general understanding of society in Danish civil defence in stressing the social norms of conscientiousness and community spirit (Bjørnsson, Farbøl and Sylvest 2020). Acquainting civil defenders and civilians alike with the mass death that loomed in the shadow of the mushroom cloud, the ruin towns educated them in the right behaviour to avoid panic (see also Bjørnsson 2020; Sylvest 2018).

\section{CONCLUSIONS}

This chapter has attempted to demonstrate how a study of ruin towns can develop existing civil defence history by bringing an appreciation of the 
textured and spatialised, experiential and embodied nature of sociotechnical imaginaries. The framework of sociotechnical imaginaries attunes us to both the central role of technology in civil defence and the coproduction of ideas and materialities, which is clearly exemplified by the imagineering of the ruin town. However, this chapter also demonstrates, first, an embedding-extension fuzziness and, second, that a deeper understanding of materiality is necessary to understand the multiple and complex ways that matter matters. Economic restraints impeded the realisation of the British-inspired grand design for a ruin town, yet the idea and inspiration extended easily across borders. Danish civil defence authorities were eager to import and replicate the British imaginary and the technical know-how to materialise it. Whereas extension in Jasanoff's version seems to be a result of an assertion of power by the hegemonic actor over the less powerful, whether this is desirable or not, here we are clearly dealing with what we can call 'extension by invitation' (with a rephrasing of Geir Lundestad's famous title 'Empire by invitation' [1986]).

Instead of a British village, the ruin town took the shape of a Danish provincial town; it was extended into a new national context and a new architectural tradition. Here, however, the linearity of the phases is broken, because this extension cannot be understood separately from the simultaneous embedding of a particular civil defence sociotechnical imaginary that emphasised resilience, survival and regeneration, where welfare triumphed over warfare. Through the trans-spatial structure of the standard ruin, the imaginary was then re-extended across the Danish civil defence landscape as more than 20 provincial towns all over Denmark built their own ruins of resilience during the 1960s and 1970s. Centralised state planning and design resulted in nearly identical sites and built structures with only minor variations created by local landscape, finances and devotion to the cause of civil defence. Because of the recognisability of the standard ruin and X-town, the re-extension was at the same time a re-embedding of the imaginary in local contexts, settings, minds and emotions. It was, then, no straightforward or linear process; rather, the chapter shows embedding-extension to be a two-way process that might be analysed separately but, in reality, was complex, messy and impossible to disentangle.

To substantiate Jasanoff's notions of materiality, I have sought inspiration in ruinology and New Materialism, as well as employing methods of 
architectural analysis in addition to traditional historical methods. Architecture for civil defence was a medium for the imagination, design and construction of spaces in preparation for a moment of ultimate crisis: nuclear war (Monteyne 2011: xv), and the ruin town telescoped the anticipated global nuclear war into the local environment, entwining materiality and imaginaries. The standard ruin in particular and the ruin town in general expose the threat perceptions of the imaginary war that shaped the organisation of Danish civil defence. While the ruins reflected civil defence's preparation for what they were capable of acting on, the material structures themselves also became agents of continuity. The wartorn town in brick and concrete fostered a form of path dependency that contributed to an inertia and sturdiness in the perception of the future war and how it could be mitigated.

The ruin town's main raison d'être was the (imitation of) realism and authenticity, which made it possible to rehearse and pre-enact the imagined future war. The civil defence exercises that took place among the ruins attempted to foster a special—and spatial—idea of a Third World War balancing between utopian salvation and dystopian obliteration. Unlike real ruins in war-torn cities, the ruin towns were predictable, predesigned and predetermined, and they standardised an unknowable future. They made it possible to assert control over the thought and behaviour of the users and spectators by conforming to coercive programmes of use and preestablished ideologies to enforce a unity of meaning and materiality (Wood 1993), but they also structured and set the limits of imagination, which testifies to the solidity as well as agency of things.

In effect, the ruin town contributed to a taming of the unknown and unknowable catastrophe. It demonstrates the 'blurred the lines between real and imagined realities' (Jasanoff 2015a: 5); the 'real' reality of insurmountable destruction by thermonuclear warfare was tamed through a collective desire for logic and order to produce an imagined reality of a manageable urban calamity and an authoritative but normative representation of how the war ought to and would play out - and namely, how it was eventually managed and overcome.

The ruin town gave shape, mass and solidity to the imagined nuclear catastrophe, to the horror, danger, darkness, agony and fatalities associated with it. Yet it did not present the end of the world as it was known. Far from an 'architecture of disillusion' (Vidler 2010), the ruins, rather, suggested the resilience and eventual triumph of the welfare state 
and existing social order and norms in a postwar world. It thus reflected and reinforced a specific, historically situated sociotechnical imaginary in which the 'good society' was protected from the ultimate social, political and environmental chaos, the nuclear war.

Acknowledgements The author wishes to extend her sincere gratitude to the personnel at the Danish Emergency Management Agency and the municipal Emergency Management organisations who have provided invaluable assistance and gratuitously taken her on tours through the ruin towns of Denmark. In particular, she would like to thank Eva-Marie Nielsen (Tinglev), Thorbjørn Jørgensen (Kirstinesminde), Daniel Birkebæk (Odense), Basse Vængtoft (Hedehusene) and Jan Nedza and Søren Korsgaard (Rørdal).

\section{Notes}

1. RA, ES 132 Diverse rapporter og betænkninger, 3L 'Rapport over undertegnede og arkitekt Gruts rejse til England...', 1951.

2. Vestjyden "'Civilforsvarets leder hjem fra England efter at have studeret instruktørskole', 21 April 1951, 6.

3. This literature is focused on 'real' ruins: buildings that have become ruins as a result of neglect, accident or war. Still, there are a number of insights, understandings and ideas that are fruitfully harnessed also to a study of artificial ruins.

4. RA, ES $132 / 3$.

5. RA, ES 132/3 'Rapport over...', 1951.

6. RA, ES 132 'Tillæg', 1951.

7. This part of the chapter is primarily based on unarchived sources from the technical school in Tinglev kindly placed at the author's disposal by section leader Eva Marie Nielsen in February 2020: BRS Tinglev, files 'Ruinanlæg', Notes about the ruin town 'Ruinbyen i Tinglev' by K. M. Nielsen, dated December 1955; BRS Tinglev, files 'Diverse' M. Hedges, 'Denmark's system of mobile columns', The Municipal Journal, 25 September 1959; Vestkysten 28 June 1968, 'Fra krigshjælpsarbejde til opgaver i fredstid', 7; Ekstra-Bladet, 21 December 1961 'Han byggede en ruinby'. Nielsen was key to the construction of the ruin town, which was described by the later director general of the DCDD as basically a 'one man job', Rigsarkivet (henceforth RA), Beredskabsstyrelsen 
(henceforth BS), Landsarkivet for Sønderjylland (henceforth LS) ME/-879 Teknisk skole, Skolebefalinger, April 1961.

8. BRS Tinglev, 'Ruinbyen i Tinglev', 1955.

9. See blueprint in BRS Tinglev, files 'Ruinanlæg' as well as description in 'Ruinbyen i Tinglev', 1955.

10. BRS Tinglev'Ruinbyen i Tinglev', 1955; Horsens Social-Demokrat, 13 January 1959 'En uhyggelig ruinby, der 'kun' kostede 20.000 kr.', 3.

11. RA ES Breve 62/Breve 1957-1958 Letter from Schultz to Abelin dated 11 February 1958. Interestingly, Schultz sent Grut's original blueprints to his Swedish counterpart, but whether the plans were realised in Sweden is not clear.

12. 13 January 1959 , p. 3. Falfield had 22 buildings according to Petersen's report, compared to Tinglev's six. The article also exaggerated in claiming the price of Falfield was DKK 2 million and Tinglev just DKK 10,000. See also Jydske Tidende (JT) 19 November 1955 'Ruinby i København efter tegninger fra Tinglev', 9.

13. JP 9 March 1957 'Civilforsvaret får nu en teknisk skole i Tinglev', 6.

14. Berlingske Tidende, 29 January 1962 'De lærer civilforsvar i sønderjysk ruinby', 8; Herning Folkeblad (HF), 2 October 1961 'Fra Hamborg til Tinglev for at studere - ruiner', 3; Horsens SocialDemokrat, 13 January 1959; JP, 9 March 1957; JT, 19November 1955; Vestkysten, 9 February 1962 'Hele Esbjergs civilforsvar til stor øvelse i 'Ruinbyen', 14; Vestkysten, 16 September 1969 'Tinglevs store ruinby giver inspiration til tre norske CF-ledere',17; Vestkysten, 21 January 1975 'Arabisk CF-general på besøg i Tinglev', 2; JT, 25 May 1968 'Nordisk kontakt i civilforsvaret'; JT, 31 January 1975 'Saudi-arabere lærer civilforsvar'; JT, 28 October 1966 'Thailændere på CF-skolen'.

15. BRS Tinglev, file Ruinanlæg, blueprint and map from 1958; Rigsarkivet (henceforth RA), Beredskabsstyrelsen (henceforth BS), Landsarkivet for Sønderjylland (henceforth LS) ME/-879 Teknisk skole, Skolebefalinger, January 1960, April-May 1961.

16. Civilforsvarsbladet 1963:10. Seks øvelsesanlæg sættes i gang, 15.

17. There were four facilities in CD region I (Northern Jutland), including Rørdal, Hobro and Hvims (a cooperation between the towns Skagen, Frederikshavn, Sxby, Hjørring and Hirtshals); 
seven in region II (mid-Jutland), incl. Holstebro, Randers, Århus, Viborg, Herning; four in region III (Southern Jutland), incl. Gudsø (cooperation between Vejle, Fredericia, Kolding and Middelfart), Horsens, Esbjerg; three in region IV (Funen and islands), Assens, Odense, Svendborg; four in region V (SouthWestern Sealand), incl. Næstved and Nykøbing F.; three in region VI (Northern Sealand and Copenhagen), Helsingør, Køge and Birkerød, later Hedehusene; and finally one in region VII (Bornholm), Rønne. In addition, there were a number of 'mini training facilities'. RA, Årsrapport 1972 and 1977.

18. Molitor notes how West German civil defence thrived in détente periods, not during crises, see Chapter 3 this volume.

19. Vendsyssel Tidende, 22 May 1966 'Byen i Hvims, hvor man bygger vakkelvorne huse', 15.

20. This description of the standard ruin and the blueprints are all located at Aarhus Municipality's online archive of construction projects, 'Min ejendom' https://minejendom.aarhus.dk/Byg gesag/Liste?adresseId $=58345$ [accessed 10 February 2020], see specifically Byggesag 65-79 'Entreprisebeskrivelser' and 'Etageplaner'.

21. Vendsyssel Tidende, 22 May 1966 'Byen i Hvims, hvor man bygger vakkelvorne huse', 15.

22. Odense, Åsumvej 55, Ejby, Odense Jorder, 1h, journalsag 577 Standardøvelsesanlæg, 1159 'Flyt. Undervisningsb.', 1055 'Tilbygning' https://www.weblager.dk/app [accessed 10 February 2020].

23. AS, Århus Kommune Byrådet Journalsager 1985, 'Projekt 1976'. See also Aarhus Municipality's online archive of construction projects https://minejendom.aarhus.dk/Byggesag/Liste?adr esseId $=58345$ [accessed 10 February 2020].

24. BRS Tinglev 'Ruinbyen i Tinglev', 1955.

25. A similar bypassing of the dangers of radioactivity is noted by Hogg in his chapter on civil defence exercises in Britain, see Hogg this volume.

26. Vestkysten 10/6/1970 'Atombombe' sprænges på tirsdag ved Søgård'; JT 16 June 1970 'A-bombe' øvelse'; JT 10 August 1971 'CF sprænger mini-atombombe'.

27. Unfortunately, civil defence exercise scenarios have not been saved for posterity at Tinglev or any other of the ruin town that has been 
selected for field studies; hence, the primary descriptions of these exercises still in existence are brief newspaper reports.

28. Vestkysten, 17-18 December 1983 'Atom-truslen sætter helt ny uddannelse i gang på CF-skole'.

29. JT, 20 April 1986 'Da bomberne ramte Tinglev'; Personal conversation with former CD officers H. A. J. Larsen, Barak Hl Beredskabsforbundets informations- og udstillingsbarak, 12 February 2020 and Thorbjørn Jørgensen, Civil Emergency Preparedness Inspector at Aarhus Beredskabscenter, 13 February 2020.

30. Personal conversation with H. A. J. Larsen 12 February 2020 and Thorbjørn Jørgensen 13 February 2020.

31. RA, ES 132 'Tillæg', 1951.

32. As Cronqvist and Grant (this volume) remind us, individuals experienced civil defence in numerous different ways, and it is beyond the scope of this chapter to evaluate the degree of success of extending a specific sociotechnical imaginary to a wider population through the ruin towns. The reassuring message of resilience and survival was certainly picked up by national and local newspapers, but whether the population accepted and internalised this sociotechnical imaginary remains a question for future research.

33. Berlingske Tidende, 29 January 1962; Bornholms Tidende, 1 December 1969 'CF-øvelse årsag til blind brandalarm', 4; Fredericia Dagblad, 23 January 1960 'CF-ruinbyen endnu kun en ønskedrøm blandt lederne', 3; Fynsk Aktuelt, 26 October 1965, 'Arkitekttegnet ruin kostede 50.000 kr.', 6; HF 2 October 1961; $H F, 23$ October 1976 'Hård brandtørn for genindkaldte CFere', 3; Horsens Social-Demokrat, 13 January 1959, 3; JP 9 March 1957; JP, 20 April 1959 'Atombombeøvelse i Ruinbyen i Tinglev', 3; Middelfart Venstreblad, 26 October 1965 'Mange mænd træner mange timer for a t redde - ja måske Dem', 4; Skagen Avi,s 14 January 1961; Vendsyssel Tidende, 22 May 1966; Vestkysten, 9 February 1962; Vestkysten, 9/4/1962 'Esbjerg CFs effektivitet bevist ved realistisk øvelse i Tinglev', 8; Vestkysten, 28 June1968; Aalborg Stiftstidende, 19 February 1965 'Bevilling givet til ruinhus i Rørdal', 1-2; JP, 20 April 1959.

34. Vestkysten, 9 April 1962 'Esbjerg CFs effektivitet bevist ved realistisk øvelse i Tinglev', 8.

35. JP, 24 February 1975 'CF-værnepligtige viste manglende rutine på øvelse', 2. 


\section{REFERENCES}

\section{UNPUbLISHED SOURCES}

BRS Tinglev: Beredskabsstyrelsen Tinglev [the Danish Emergency Management's Technical School Tinglev].

1. BRS Tinglev, files 'Ruinanlæg'.

2. BRS Tinglev, files 'Standard øvelsesanlæg'.

3. BRS Tinglev, files 'Diverse'.

RA: Rigsarkivet [the National Archives] Beredskabsstyrelsen.

4. RA, ES Erik Schultz Embedsarkiv, 62 Breve 1957-58.

5. RA, ES 132 Diverse rapporterog betænkninger.

6. RA ES 231 Årsrapporter.

RA, LS: Landsarkivet for Sønderjylland [Regional archives of Southern Jutland] Beredskabsstyrelsens tekniske skole [Danish Emergency Management Agency's technical school], ME/-879, skolebefalinger [school orders].

AS: Aarhus Stadsarkiv [Aarhus City Archives],

7. AS ÅrhusKommune Byrådet Journalsager 1985, 1692 'Projekt 1976'.

\section{ONLINE SOURCES}

https://minejendom.aarhus.dk/Byggesag/Liste?adresseId=58345 [10/2/2020] Aarhus Municipality's online archive of construction projects https://www.weblager.dk/[10/2/2020] Online archive of municipal construction projects in Denmark.

\section{NEWSPAPERS}

Aalborg Stiftstidende.

Berlingske Tidende.

Bornholms Tidende.

Ekstra-Bladet.

Fredericia Dagblad.

Fynsk Aktuelt.

Herning Folkeblad (HF).

Horsens Social-Demokrat.

Jyllands-Posten (JP).

Jydske Tidende (JT).

Middelfart Venstreblad.

Roskilde Dagblad.

Vejle Amts Folkeblad.

Vendsyssel Tidende. 
Vestjyden Esbjerg.

Vestkysten.

Skagen Avis.

Sønderjyden.

\section{LITERATURE}

Bennett, Tony and Patrick Joyce, eds. 2010. Material powers: Cultural studies, history and the material turn. London and New York: Routledge.

Beredskabsstyrelsen. 2006. Beredskabsstyrelsens Tekniske Skole $i 50$ ar: fra folkebøjskole til beredskabsskole. Tinglev: Beredskabsstyrelsen, Teknisk skole.

Bishop, R. and G. Clancey. 2004. The City-as-Target, or Perpetuation and Death. In Cities, war, and terrorism: Towards an urban geopolitics, ed. Graham Stephen, 54-75. Oxford: Blackwell.

Bjørnsson, Iben. 2020. 'Stands tilløb til panik'. Civilforsvarspjecer som social kontrol. In Atomangst og civilt beredskab: Forestillinger om atomkrig $i$ Danmark 1945-1975, eds. Marianne Rostgaard and Morten Pedersen, 65102. Aalborg: Aalborg Universitetsforlag.

Bjørnsson, Iben, Rosanna Farbøl and Casper Sylvest. 2020. Hvis krigen kommer: Forestillinger om fremtiden, Kulturstudier 11: 33-61.

CF-samvirket Gudsø $i 25$ ar (1987).

Civilforsvarsbladet 1963:10. Seks øvelsesanlæg sættes i gang, 15

Civilforsvarsbladet 1974:2. Poeten og lillemor i CF's tjeneste, 11.

Civilforsvarsstyrelsen. 1965. Larebog $i$ redningstjeneste. København: J.H. Schultz Universitets- Bogtrykkeri.

Civilforsvarsstyrelsen. 1971. Lerebog $i$ brandtjeneste. København: J.H. Schultz Universitets- Bogtrykkeri.

Clarke, Lee. 1999. Mission improbable: Using fantasy documents to tame disaster. Chicago: University of Chicago Press.

Cordle, Dan. 2012. Protect/Protest: British nuclear fiction of the 1980s. British Journal for the History of Science 45: 653-69.

Dahl, Arthur. 1955. Countering vulnerability. Danish Foreign Office Journal 1: 16-18.

Davis, Tracy 2007. Stages of emergency: Cold War nuclear civil defense. Durham: Duke University Press.

Derrida, Jacques. 1984. No apocalypse, not now (Full speed ahead, seven missiles, seven missives). Diacritics 14: 20-31.

Deville, Joe, Michael Guggenheim and Zuzana Hrdličková. 2014. Concrete governmentality: shelters and the transformations of preparedness. The Sociological Review 62(S1): 183-210.

Edensor, Tim. 2005. Industrial ruins. Space, aesthetics and materiality. New York: Berg. 
Eshel, Amir. 2010. Layered time: Ruins as shattered past, ruins as hope in Israeli and German landscapes and literature. In Ruins of modernity, eds. Julia Hell and Andreas Schörle, 133-151. Durham and London: Duke University Press.

Farbøl, Rosanna. 2020. Urban civil defence: Imagining, constructing and performing nuclear war in Aarhus. Urban History, 1-23https://doi.org/10. $1017 /$ S0963926820000590

Frohman, Larry. 2011. Tony Bennett and Patrick Joyce (eds.) Material powers. Cultural studies, history and the material turn. Social History 36: 378-380.

Grant, Matthew. 2010. After the Bomb: civil defence and nuclear war in Britain, 1945-68. London: Palgrave Macmillan

Hell, Julia and Andreas Schörle. 2010. Introduction. In Ruins of modernity, eds. Julia Hell and Andreas Schörle, 1-17. Durham and London: Duke University Press.

Hogg, Jonathan. 2012. 'The family that feared tomorrow': British nuclear culture and individual experience in the late 1950s, British Journal for the History of Science 45: 535-549.

Huyssen, Andreas. 2010. Authentic ruins: Products of modernity. In Ruins of modernity, eds. Julia Hell and Andreas Schörle, 29-41. Durham and London: Duke University Press.

Ireland, Tracy and Jane Lydon. 2016. Rethinking materiality, memory and identity. Public History Review 23: 1-8.

Jasanoff, Sheila. 2015a. Future imperfect: Science, technology and the imaginations of modernity. In Dreamscapes of modernity, eds. Sheila Jasanoff and Sang-Huyn Kim, 1-33. Chicago: Chicago University Press.

Jasanoff, Sheila. 2015b. Imagined and invented worlds. In Dreamscapes of modernity, eds. Sheila Jasanoff and Sang-Huyn Kim, 321-341. Chicago: Chicago University Press.

Jasanoff, Sheila and Sang-Huyn Kim, eds. 2015. Dreamscapes of modernity: Sociotechnical imaginaries and the fabrication of power. Chicago: Chicago University Press.

Lifton, Robert Jay. 1982. Beyond psychic numbing: a call to awareness. American Journal of Orthopsychiatry 52: 619-629.

Masco, Joseph. 2005/2006. Fantastic city: Engineering Ruins in Cold War America. Cabinet 20: 1-6.

Masco, Joseph. 2008. 'Survival is Your Business': Engineering ruins and affect in nuclear America. Cultural Anthropology 23: 361-398.

Monteyne, David. 2011. Fallout shelter: Designing forcivil defense. Minneapolis, MN: University of Minnesota Press.

Monteyne, David. 2004. Shelter from the elements: Architecture and civil defense in the early Cold War. The Philosophical Forum 35: 179-199. 
Puff, Helmut. 2010. Ruins as models: Displaying destruction in postwar Germany. In Ruins of modernity, eds. Julia Hell and Andreas Schörle, 253-70. Durham and London: Duke University Press.

Stafford, James. 2012. 'Stay at home': The politics of nuclear civil defence, 196883. Twentieth Century British History 23: 383-407.

Sylvest, Casper. 2018. Atomfrygten og civilforsvaret. temp - tidsskrift for historie 16: 16-39.

Sylvest, Casper. 2021. Pre-enacting the next war: The visual culture of Danish civil defence in the early nuclear age. Cold War History, 1-23. https://doi. org/10.1080/14682745.2021.1874932

Vidler, Anthony. 2010. Air war and architecture. In Ruins of modernity, eds. Julia Hell and Andreas Schörle, 29-41. Durham and London: Duke University Press.

Weizman, Eyal. 2007. Hollow land: Israel's architecture of occupation. London: Verso.

Weizman, Eyal. 2011. The least of two possible evils: Humanitarian violence from Arendt to Gaza. London: Verso.

Weizman, Eyal. (2012) Forensic architecture: Notes from fields and forums. Ostfildern: Hatje Cantz.

Wood, Lebbeus. 1993. War and architecture: Rat $i$ arhitektura, Pamphlet Architecture 15. Princeton: Princeton Architectural Press.

Open Access This chapter is licensed under the terms of the Creative Commons Attribution 4.0 International License (http://creativecommons.org/licenses/ by $/ 4.0 /)$, which permits use, sharing, adaptation, distribution and reproduction in any medium or format, as long as you give appropriate credit to the original author(s) and the source, provide a link to the Creative Commons license and indicate if changes were made.

The images or other third party material in this chapter are included in the chapter's Creative Commons license, unless indicated otherwise in a credit line to the material. If material is not included in the chapter's Creative Commons license and your intended use is not permitted by statutory regulation or exceeds the permitted use, you will need to obtain permission directly from the copyright holder.

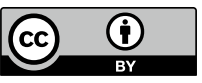

